\title{
Zootechnical performance and interaction between Penaeus schmitti Burkenroad, 1936 and Penaeus vannamei Boone, 1931 reared under laboratory conditions
}

\author{
Rafael Fernandez de Alaiza Garcia Madrigal ${ }^{1}$ \\ Ubiratã de Assis Teixeira da Silva ${ }^{2}$ \& Eduardo Luis Cupertino Ballester ${ }^{1,3}$ \\ ${ }^{1}$ Postgraduate Programme in Zoology of the Federal University of Paraná \\ Biological Sciences Sector, Curitiba, Paraná, Brazil \\ ${ }^{2}$ Integrated Group of Aquaculture and Environmental Studies, Federal University of Paraná \\ Curitiba, Paraná, Brazil \\ ${ }^{3}$ Prawn Culture Laboratory, Federal University of Paraná, Palotina Sector, Palotina, Paraná, Brazil \\ Corresponding author: Rafael F. de Alaiza (rfalaizagm@yahoo.es)
}

\begin{abstract}
To compare the zootechnical performance of the Brazilian native shrimp Penaeus schmitti and the exotic shrimp Penaeus vannamei, juveniles were grown under controlled conditions. Both species were simultaneously cultivated (monoculture) in separate 70 L plastic tanks at two different densities: 30 and 50 ind $\mathrm{m}^{-2}$. Also, in the other two treatments, both species were cultivated together (mixed), with and without feeding, at 30 ind $\mathrm{m}^{-2}$. During the experiment, $P$. vannamei generally showed a greater interest in food and voracity than $P$. schmitti. At harvest, for both stocking densities of monoculture treatments, the mean growth rate observed for $P$. vannamei was $1.0 \mathrm{~g} \mathrm{week}^{-1}$, while $P$. schmitti achieved only $0.1 \mathrm{~g} \mathrm{week}^{-1}$. The mean final weight was 10.4 $\pm 2.0 \mathrm{~g} ; 10.7 \pm 2.1 \mathrm{~g}$ for $P$. vannamei and $2.8 \pm 0.3 \mathrm{~g} ; 3.2 \pm 0.3 \mathrm{~g}$ for $P$. schmitti, for respective densities of 50 and 30 ind $\mathrm{m}^{-2}$. In the mixed treatment with feeding, while $P$. vannamei reached $11.9 \pm 1.4 \mathrm{~g}, P$. schmitti reached only $2.6 \pm 0.4 \mathrm{~g}$ in the same tank. The observed differences were 3.7 and 3.4 higher in favor of $P$. vanname $i$ in the monoculture treatment, and up 4.5 times higher in the mixed treatment. Under strict fasting conditions, both species practiced predation/cannibalism among themselves. The results reflected the zootechnical advantages of $P$. vannamei, but also corroborated the negative effect that high densities and lack of natural food can exert over native species. The potential for $P$. schmitti cultivation and the possible impact of the escape of $P$. vanname $i$ into the natural environment is discussed.
\end{abstract}

Keywords: Penaeus schmitti; Penaeus vannamei; white shrimp; marine shrimp farming; penaeid; ethology

\section{INTRODUCTION}

The wide geographic distribution of populations of the white shrimp, Penaeus schmitti Burkenroad, 1936 along the Atlantic coast of the Americas (FAO, 2016), is only one of the many reasons justifying the interest of researchers, mainly in Brazil, Venezuela, Mexico, and Cuba. Biological aspects such as age, growth, distribution and population structure of the white shrimp P. schmitti, in natural populations, has been studied in Venezuela (Andrade \& Pérez, 2004, 2007; Gassman \& Rojas, 2016), in Nicaragua (VelázquezChavarría, 1999) and the Brazilian coast, in the states of Rio Grande, do Norte, Paraíba, Pernambuco, Alagoas and Sergipe (Santos et al., 2006), and in Rio de Janeiro (Carvalho, 2013).

Also, studies over natural populations have been pointed out the decrease of the natural populations of this species, due to intensive fishing and the reduction of freshwater intake caused by river damming, which affects the populations of $P$. schmitti, highly linked to the fluvial contribution (Sosa, 2009; Silva et al., 2018).

Studies on $P$. schmitti also included aquaculture oriented biological aspects, such as growth (Fugimura, 2009; Carvalho, 2013), nutrition (Jaime-Ceballos, 2006; Álvarez, 2007; Galindo-López, 2009), metabolism

Corresponding editor: Fernando Vega 
(Barbieri, 2010; Girotto, 2010; Barbieri et al., 2016a), the effects of pollution (Santos et al., 2014), and the economic feasibility of production (Castilho-Barros, 2013).

Experiments with $P$. schmitti on the pilotcommercial scale, nurseries wand grow-out ponds were also carried out in Cuba (Fernández de Alaiza \& JaimeCeballos, 1990; Fernández de Alaiza et al., 1994a,b). In addition, given the importance of commercial cultivation of this species in that country for several years, aspects related to feeding and commercial feed formulation were also studied, to accelerate growth and reduce production costs (Fraga et al., 2002; Jaime-Ceballos \& Galindo-López, 2006; Fraga-Castro \& Jaime-Ceballos, 2011). Also, genetic engineering techniques were applied, transferring to $P$. schmitti the tilapia growth hormone gene (Arenal et al., 2008).

Effect of stocking density on the growth of $P$. schmitti in captivity was studied by Marquez et al. (2012), finding that densities of up to 50 ind $\mathrm{m}^{-2}$ negatively affect the crop weight and the weekly weight increase, but allow a higher yield. Henriques et al. (2014), studied the growth of the species in intensive cultivation to produce live bait, concluding that the growth parameters of $P$. schmitti cultivated in these conditions were similar to those reported in the literature for natural populations. Likewise, De Barros et al. (2014) analyzed the economic viability of intensive white shrimp production as bait for sport fishing; the results indicated a commercial opportunity for small producers due to the attractive selling prices.

On the other hand, marine shrimp farming in the Americas and the world is currently dedicated to the cultivation of the Pacific whiteleg shrimp Penaeus vannamei. From USA to Brazil, almost the totality of the farms along the entire coast cultivates this species, even though it is considered an exotic species in Atlantic waters (Jory, 2017). Several studies have documented escapes of $P$. vannamei from farms to the natural environment at least since 2000, in Brazil (Santos \& Coelho, 2002; Santos, 2005; Barbieri \& Melo, 2006; Loebmann et al., 2010), 1988, in Texas, USA (Balboa et al., 1991) and since 2011, in Tabasco, Mexico (Wakida-Kusunoki et al., 2011).

As much as for $P$. schmitti in the past, $P$. vannamei has become a thoroughly studied species in recent years, mainly in terms of aquaculture aspects (Williams et al., 1996; Rosas et al., 2001; Tacon et al., 2002; Arzola et al., 2008; Santos et al., 2009; Brito et al., 2014; Fóes et al., 2016; Khanjani et al., 2016; Maciel et al., 2018). Although extensive literature about the cultivation of both species is available, only one direct zootechnical performance comparison was found (Allessi, 2000).
The objective of this study was to evaluate the zootechnical potential of $P$. schmitti as a base for its cultivation on the Atlantic coast of Central and South America, compared to the performance of $P$. vannamei produced under the same experimental conditions. Also, the effect of interaction between these species during a joint production was evaluated.

\section{MATERIALS AND METHODS}

\section{Experimental organisms}

For the experiment, juveniles of both species with similar size and weight were acquired. Penaeus vannamei postlarvae (PL), with 19 days after metamorphosis (PL19), were obtained from a commercial larviculture laboratory (Atlântico Sul Maricultura Ltda., Santa Catarina, Brazil) in November 2016. The mean weight of PL's at arrival was $10.6 \pm 0.6 \mathrm{mg}$. These postlarvae were bred from nauplii produced in a different commercial hatchery (Aquatec Aquacultura Ltda., Rio Grande do Norte, Brazil). The nauplii were obtained from genetically selected (Speed Line) and specific pathogen-free (SPF) progenitors.

The Penaeus schmitti juvenile shrimp were collected in January 2017 by artisanal fishermen using both a cast net of 5-6 mm mesh size and a traditional fishing net called "gerivald." The sampling region, known as "Seco da Calçada," is located in the bay of Guaratuba, Paraná, Brazil (2548’28”S, 48³6’04”W). The animals were positively identified according to the characteristics described by Pérez-Farfante (1970, 1988). The weight and total length of juveniles at arrival were $1.14 \pm 0.45 \mathrm{~g}$ and $57 \pm 8.6 \mathrm{~mm}$, respectively.

Postlarvae and juveniles of both species were transferred to the Marine Aquaculture, and Restocking Centre (CAMAR), which belongs to the Integrated Group of Aquaculture Environmental Studies (GIA) and the Federal University of Paraná (UFPR), in Pontal do Paraná, Paraná, Brazil.

$P$. vannamei specimens arrived with transportation water at a salinity of 15 , and the juveniles of $P$. schmitti, with a salinity of 20 . Animals were acclimated to the laboratory salinity, which in the rainy season (December to March), oscillates between 27 and 34. In both cases, the salinity acclimation rate was $0.5 \mathrm{~d}^{-1}$. In the experimental tanks, the salinity was maintained between 30 and 31 .

Both species were kept for 15 days in separate 1,000 L tanks to obtain better size standardization. During this period, the animals were adapted to the experimental routine, that is, daily water renewal of $50-75 \%$ and the use of feeding trays, at pre-established times. 
During this stage, both species were fed with: "Epac XL" and "Stresspak 5/8" (45 and 40\% protein, respectively), both of INVE Aquaculture - Health Division, and later with the commercial shrimp feed "Guabi Poti Mirim QS 40J" (40\% crude protein). The food was supplied ad libitum, but at the same time, preventing the remains of unconsumed food from affecting the quality of the water. The ration was calculated as $20 \%$ of the biomass. The percentage was reduced daily to $4 \%$ as the size of the individuals increased. After the established resting period, juveniles of both species of similar size and weight were obtained.

In order to further select shrimp of the same size for both species, a method commonly employed in Japanese shrimp hatcheries were used. Plastic screens with 8 and $10 \mathrm{~mm}$ meshes were placed inside a strong aerated 1,000 L plastic tank (Fig. 1). The largest mesh was placed on top of the smaller one, so when juveniles were placed in the water, they would immediately try to cross both meshes to reach the tank bottom. This technique exploits shrimp's instinct to distribute themselves in the tank, searching for the site with the lowest possible congener density.

With the use of this method, different size shrimp were separated. In the end, the wet weight and the mean total length of the $P$. schmitti shrimp at the beginning of the experiment were $1.79 \pm 0.4 \mathrm{~g}$ and $61 \pm 0.4 \mathrm{~mm}$, and for $P$. vanname $i$ were $1.71 \pm 0.4 \mathrm{~g}$ and $61 \pm 0.5 \mathrm{~mm}$, respectively. The individuals were measured using a digital caliper (Mitutoyo ${ }^{\circledR}$ Mod. 500-196-30) and weighed using a precision digital scale (Marte ${ }^{\circledR}$, Mod. AL 500C, with a precision of $0.001 \mathrm{~g}$ ). The total shrimp length was measured from the anterior rostrum end to the posterior edge of the telson. At the end of that process, it was found that the outer appearance of the shrimps of both species was very similar. Nevertheless, some differences can be distinguished, which are discussed at the end of this paper.

\section{Experimental system}

The experimental units consisted of rectangular white plastic boxes with $50 \mathrm{~L}$ of nominal (effective) capacity and bottom area of $0.2 \mathrm{~m}^{2}$. The experimental setup was assembled in an experimental room, containing 30 tanks, each of them covered with a black plastic mesh of $1 \mathrm{~mm}$ and provided with artificial aeration. The experimental room was under natural light and $13: 11 \mathrm{~h}$ light:dark photoperiod.

The experimental system was filled with filtered ( 5 $\mu \mathrm{m}$ cartridge filters) seawater, in an open water exchange circuit. The total daily water exchange volume was at least $100 \%$.
The following water quality variables were monitored daily: temperature $\left({ }^{\circ} \mathrm{C}\right)$, with a thermometer, dissolved oxygen $\left(\mathrm{mg} \mathrm{L}^{-1}\right)$ and oxygen saturation (\%), with a digital oximeter (YSI-550A, USA), as well as salinity, with an optical refractometer (Instrutemp, Brazil) and $\mathrm{pH}$, with a digital $\mathrm{pH}$ meter (AZ-86505, Taiwan). The concentration of nitrite $\left(\mathrm{mg} \mathrm{L}^{-1} \mathrm{~N}^{-\mathrm{NO}_{2}}{ }^{-}\right)$ (APHA, 1995) and total ammonia (mg L ${ }^{-1} \mathrm{~N}-\mathrm{AT}$ ) (APHA, 2005) by the indophenol method, were obtained weekly, using a Spectronic 20 Genesys (USA) spectrophotometer. The experiment was executed from February to April 2017, for 60 days.

\section{Treatments}

The experimental setup was specially designed to evaluate the effect of different densities on the growth rates on each of the tested species. Two different densities were established in the experiment: 6 and 10 ind $\operatorname{tank}^{-1}$ (equivalent to 30 and 50 ind $\mathrm{m}^{-2}$ ) for each species, representing treatments 1 to 4 (Table 1). Besides, the design aimed to evidence the effect of intraspecific competition in the presence and absence of feeding, representing treatments 5 and 6 .

The experiment started with 110 individuals of each species randomly distributed in the experimental tanks. Dead animals were not replaced until the end of the 60 days of trial. The culture conditions were maintained the same for all tanks.

\section{Food management}

During the experiment, the animals were fed commercial shrimp feed (Guabi Poti Mirim QS 40J with $40 \%$ of crude protein). Since it was a growth study, the food was offered ad libitum. However, in order to prevent excess feeding, which could affect the water quality, the amount of feed offered was adjusted according to the consumption observed. The food was given twice daily at 09:00 and 20:00 $\mathrm{h}$.

The shrimp were checked four times a day: at 08:00 $\mathrm{h}$ when the residues of food and feces were siphoned, and the water exchanged, at 11:00, 14:00, and 19:00 h, when a second water exchange was carried out to eliminate the floating foam before the last feeding of the day. The number of molts in each tank was also recorded daily.

\section{Biometrics and analysis}

As already mentioned, before the beginning of the experiment, the total length $(\mathrm{mm})$ and the total wet weight $(\mathrm{g})$ was measured. The shrimp's total length was measured from the anterior end of the rostrum to the posterior edge of the telson. Ethological observations were made during the daily handling of the shrimp, i.e., 

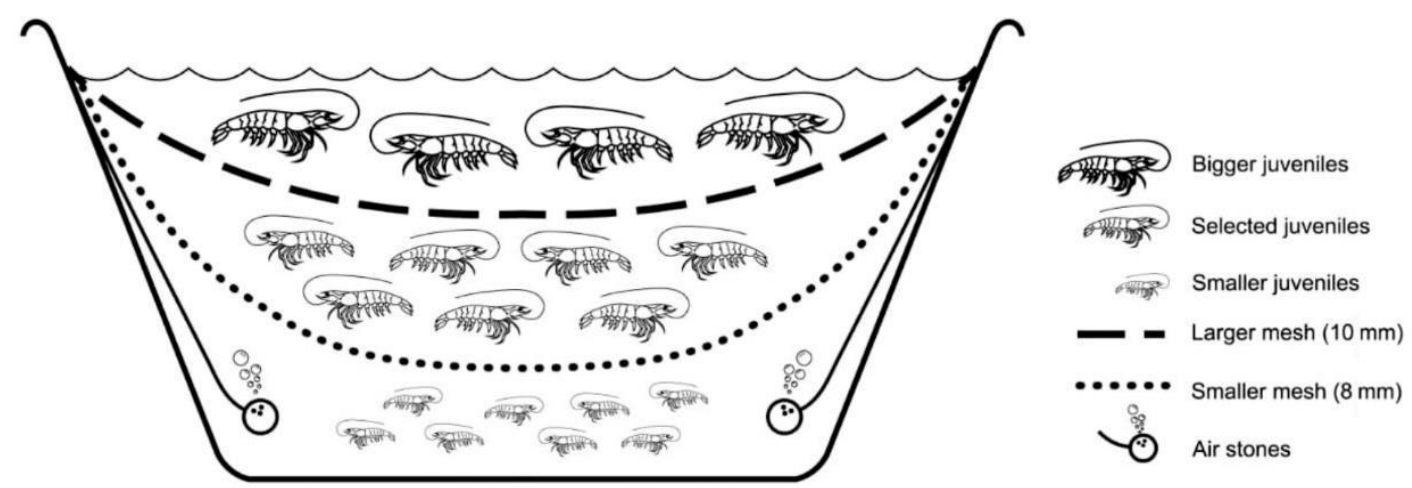

Figure 1. Scheme of a $1000 \mathrm{~L}$ tank with plastic meshes, used to separate live juveniles, according to their size. Illustration by R.F. de Alaiza Amador (2018).

Table 1. Treatments applied during the experiment with Penaeus schmitti and P. vannamei for 60 days, simultaneously. In the comparison in pairs (between species), in lines with the same stocking density, different letters indicate significant differences $(P<0.05)$. ANOVA: $* \mathrm{~F}_{(1.98)}=0.85, P=0.359 ; * * \mathrm{~F}_{(1.58)}=1.80, P=0.184 ; * * * \mathrm{~F}_{(1.28)}=0.39, P=0.535 ; * * * \mathrm{~F}_{(1.28)}$ $=0.02, P=0.891$. SD: standard deviation.

\begin{tabular}{|c|c|c|c|c|c|c|}
\hline Treatment & Species & $\begin{array}{c}\mathrm{N}^{\circ} \\
\text { ind } \operatorname{tank}^{-1}\end{array}$ & $\begin{array}{l}\text { Density } \\
\left(\text { ind } \mathrm{m}^{-2} \text { ) }\right.\end{array}$ & $\begin{array}{c}\text { Initial mean } \\
\text { weight } \pm \mathrm{SD}(\mathrm{g})\end{array}$ & Food & $\begin{array}{c}\mathrm{N}^{\circ} \text { of } \\
\text { replicates }\end{array}$ \\
\hline 1 & P. schmitti* & 10 & 50 & $1.783 \pm 0.33 \mathrm{a}$ & Yes & 5 \\
\hline 2 & P. vannamei* & 10 & 50 & $1.713 \pm 0.42 \mathrm{a}$ & Yes & 5 \\
\hline 3 & P. schmitti** & 6 & 30 & $2.04 \pm 0.30 \mathrm{~b}$ & Yes & 5 \\
\hline 4 & P. vannamei** & 6 & 30 & $1.91 \pm 0.45 b$ & Yes & 5 \\
\hline 5 & $\begin{array}{l}\text { P. schmitti \& } \\
\text { P. vannamei*** }\end{array}$ & $3 / 3$ & 30 & $\begin{array}{l}1.657 \pm 0.31 \mathrm{c} \\
1.586 \pm 0.31 \mathrm{c}\end{array}$ & Yes & 5 \\
\hline 6 & $\begin{array}{l}\text { P. schmitti \& } \\
\text { P. vannamei } * * * *\end{array}$ & $3 / 3$ & 30 & $\begin{array}{l}1.424 \pm 0.199 \mathrm{~d} \\
1.413 \pm 0.223 \mathrm{~d}\end{array}$ & No & 5 \\
\hline
\end{tabular}

primarily during the day. Only one researcher recorded the observations, but details of the shrimp's behavior were also discussed with the members of the work team.

Biometrics was performed, after the beginning of the experiment, every 10 days; the length and total weight were measured. At that time, the specimens were too small for sex determination. Therefore, the sex of each specimen was determined in the last sampling when they were already pre-adults.

The zootechnical variables collected at the end of the experiment were final weight $(\mathrm{g})$, final length $(\mathrm{mm})$, survival $(\%)$, feed conversion rate (FCR), growth rate $\left(\mathrm{g}\right.$ week $\left.^{-1}\right)$, and productivity $\left(\mathrm{g} \mathrm{m}^{-2}\right.$ cycle $\left.^{-1}\right)$. Thirty shrimps of each species were measured in length, weight and sex, hepatopancreas weight, and diameter of fecal threads. They were collected fresh from the bottom of separate tanks, where specimens of each species were confined. The diameter or thickness of the fecal threads was measured under an optical microscope, using an ocular micrometer, to demonstrate morphological differences between $P$. schmitti and $P$. vannamei.

The data obtained were analyzed and compared using a one-way ANOVA and the Tukey test $(P<0.05$ for all comparisons), with the use of PAST software (Hammer et al., 2001).

\section{RESULTS}

\section{Water quality variables}

During the experiment, the water temperature ranged between 22.0 and $29.0^{\circ} \mathrm{C}$, with an average of $26.1 \pm$ $1.8^{\circ} \mathrm{C}$. The mean values \pm standard deviation (SD) of the physical and chemical variables recorded during the experiment are shown in Table 2. Variables such as temperature, salinity, dissolved oxygen, and total ammonium did not present significant differences $(P<$ $0.05)$ among treatments. Other variables, such as $\mathrm{pH}$ and nitrite concentration $\left(\mathrm{mg} \mathrm{L}^{-1} \mathrm{~N}-\mathrm{NO}_{2}{ }^{-}\right)$, showed significant differences $(P<0.05)$. The $\mathrm{pH}$ was significantly lower $(7.80 \pm 0.1 ; P<0.05)$ in tanks of 
Table 2. Mean values \pm standard deviation of chemical and physical water quality variables in the culture of southern white shrimp Penaeus schmitti and whiteleg shrimp $P$. vannamei under six treatments for 60 days. Values with different letters on the same row indicate significant differences $(P<0.05)$. ${ }^{1}$ On this treatment, after 38 days the experiment finished, with the death of the last specimen of Penaeus vannamei. *ANOVA: (1) $\mathrm{F}_{(5.840)}=0.395, P=0.852$; (2) $\mathrm{F}_{(5.552)}=106.2, P=1.965 \mathrm{E}-78$; (3) $\mathrm{F}_{(5.612)}=0.811, P=0.541 ;$; 4$) \mathrm{F}_{(5.888)}=0.015, P=0.999 ;(5) \mathrm{F}_{(5.39)}=0.873, P=0.508 ;(6) \mathrm{F}_{(5.39)}=4.828, P=0.0016$.

\begin{tabular}{|c|c|c|c|c|c|c|}
\hline \multirow[b]{2}{*}{ Variable } & \multicolumn{5}{|c|}{ With food } & \multirow{2}{*}{$\begin{array}{c}\text { Fasting } \\
\text { 6-P. schmitti \& } \\
\text { P. vannamei }{ }^{1} \text { (mixed) } \\
\left(30{\left.\text { ind } \mathrm{m}^{-2}\right)}^{2}\right.\end{array}$} \\
\hline & $\begin{array}{l}\text { 1-P. schmitti } \\
\left(50 \text { ind }^{-2}\right)\end{array}$ & $\begin{array}{l}\text { 2-P. vannamei } \\
\left(50 \text { ind } \mathrm{m}^{-2}\right)\end{array}$ & $\begin{array}{l}\text { 3-P. schmitti } \\
\left(30 \text { ind }^{-2}\right)\end{array}$ & $\begin{array}{l}\text { 4-P. vannamei } \\
\left(30{\left.\text { ind } \mathrm{m}^{-2}\right)}^{2}\right.\end{array}$ & 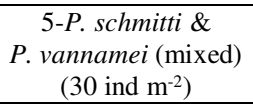 & \\
\hline Temperature $\left({ }^{\circ} \mathrm{C}\right)$ & $26.0 \pm 1.8^{\mathrm{a}}$ & $26.0 \pm 1.8^{\mathrm{a}}$ & $26.0 \pm 1.8^{\mathrm{a}}$ & $26.0 \pm 1.8^{\mathrm{a}}$ & $26.0 \pm 1.8^{\mathrm{a}}$ & $26.7 \pm 1.3^{\mathrm{a}}$ \\
\hline $\mathrm{pH}$ & $7.85 \pm 0.1^{\mathrm{a}}$ & $7.80 \pm 0.1^{\mathrm{b}}$ & $7.87 \pm 0.1^{\mathrm{a}}$ & $7.86 \pm 0.1^{\mathrm{a}}$ & $7.85 \pm 0.1^{\mathrm{a}}$ & $8.06 \pm 0.1^{\mathrm{a}}$ \\
\hline Dissolved oxygen (mg L $\left.\mathrm{m}^{-1}\right)$ & $4.5 \pm 0.5^{\mathrm{a}}$ & $4.4 \pm 0.5^{\mathrm{a}}$ & $4.5 \pm 0.5^{\mathrm{a}}$ & $4.5 \pm 0.4^{\mathrm{a}}$ & $4.4 \pm 0.4^{\mathrm{a}}$ & $4.5 \pm 0.4^{\mathrm{a}}$ \\
\hline Salinity & $32 \pm 1.2^{\mathrm{a}}$ & $32 \pm 1.2^{\mathrm{a}}$ & $32 \pm 1.2^{\mathrm{a}}$ & $32 \pm 1.2^{\mathrm{a}}$ & $32 \pm 1.2^{\mathrm{a}}$ & $31 \pm 1.2^{\mathrm{a}}$ \\
\hline Total ammonia (N-AT mg L $\left.{ }^{-1}\right)$ & $0.004 \pm 0.0002^{\mathrm{a}}$ & $0.004 \pm 0.0002^{\mathrm{a}}$ & $0.004 \pm 0.0003^{\mathrm{a}}$ & $0.004 \pm 0.0002^{\mathrm{a}}$ & $0.004 \pm 0.0002^{\mathrm{a}}$ & $0.004 \pm 0.0009^{\mathrm{a}}$ \\
\hline Nitrite $\left(\mathrm{mg} \mathrm{L}^{-1} \mathrm{~N}-\mathrm{NO}_{2}^{-}\right)$ & $0.37 \pm 0.04^{\mathrm{a}}$ & $0.40 \pm 0.05^{\mathrm{a}}$ & $0.39 \pm 0.04 a$ & $0.40 \pm 0.06^{\mathrm{a}}$ & $0.40 \pm 0.08^{\mathrm{a}}$ & $0.56 \pm 0.16^{\mathrm{b}}$ \\
\hline
\end{tabular}

treatment 2 and was significantly higher $(8.06 \pm 0.1 ; P$ $<0.05)$ in treatment 6.

\section{Zootechnical indicators}

The variation observed on the main zootechnical indicators at the end of the experiment is shown in Table 3. The experiment comparing survival rates between species did not show significant differences $(P$ $<0.05)$. The remaining indicators: total weight $(\mathrm{g})$, estimated yield $\left(\mathrm{g} \mathrm{m}^{-2}\right)$, feed conversion rate (FCR), and growth rate $\left(\mathrm{g}\right.$ week $\left.^{-1}\right)$ were significantly higher for Penaeus vannamei.

The values of weight increments are shown in Figure 2. With a growth rate of $1.0 \mathrm{~g} \mathrm{week}^{-1}$ at a stocking density of 50 juveniles $\mathrm{m}^{-2}$, the final mean weight of $P$. vannamei was 3.7 times greater than that of Penaeus schmitti, with only $0.1 \mathrm{~g}^{\text {week }}{ }^{-1}$ at the same density. In this specific case, starting from the same mean initial weight $(1.78 \mathrm{~g} P$. schmitti, and $1.71 \mathrm{~g} P$. vannamei; $P>0.05$ ), in 60 days, the difference in final mean weight was $7.6 \mathrm{~g}$.

Results were very similar when comparing treatments with lower stocking density $\left(30\right.$ ind $\left.\mathrm{m}^{-2}\right)$. The growth rates were also of $1.0 \mathrm{~g}^{\text {week }}{ }^{-1}$ for $P$. vannamei and $0.1 \mathrm{~g} \mathrm{week}^{-1}$ for $P$. schmitti. The mean weight was 3.4 times higher for $P$. vannamei, and the difference in the final mean weight between both species was $7.5 \mathrm{~g}$.

It is noteworthy that in the treatment where both species were cultivated together (mixed) with feeding, $P$. vanname $i$ reached an even higher weekly growth and final mean weight $\left(1.21 \mathrm{~g}^{\text {week }}{ }^{-1}\right.$ and $11.9 \mathrm{~g}$, respectively) when compared to treatments where it was cultivated as a single species. Conversely, $P$. schmitti cultivated in the mixed treatment score lower numbers than as a single species.
The sex ratio determined at the end of the experiment is shown. The proportion of males and females was similar, except in the fifth treatment, where the number of males of $P$. vannamei doubled the number of females.

It should be noted the high survival achieved in the fifth treatment when specimens of both species were confined together (mixed with feeding). In this treatment, only one $P$. schmitti died (ultimate survival of $93.3 \%$ ) while all $P$. vannamei survived.

\section{Fasting treatment}

No exuviae were recorded in the first days in the mixed treatment under fasting conditions, whereas in every other tank which received the regular feed, frequent molts were detected since the beginning of the experiment. On the other hand, no deaths were recorded during the first 10 days.

The first molting process observed coincided with the first mortality record, on day 11 . Freshly molted shrimp were always attacked and eaten. However, as the state of starvation advanced (day 21), the weak yet unmoulted animals began to be attacked. Although no food was supplied, the shrimp intestine (especially of $P$. vannamei) remained dark in color.

Between the days 11 and 38, all the individuals of this treatment died (Fig. 3). It is important to note that even as cannibalism or predation was observed until only one animal was left in each tank, the predominance of one species over another was not observed. Of the five replicates, individuals of $P$. schmitti preponderated in three tanks and P. vanname i in two tanks. It means that it was the species whose specimens survived, the one that reached the end in these extreme conditions.

In this treatment, as no food was provided, no increase in weight was detected. In some tanks, the 
Table 3. Results at harvest. The final quantity of males and females and zootechnical indicators obtained (in all treatments with food), after 60 days of culture. In the comparison in pairs (between species), in lines with the same stocking density, different letters indicate significant differences $(P<0.05)$. *Includes deaths from "natural" causes or from handling problems associated with low domestication. FCR: feed conversion rate.

\begin{tabular}{|c|c|c|c|c|c|c|c|}
\hline Treatment & $\begin{array}{l}\text { Species-density } \\
\text { (ind } \mathrm{m}^{-2} \text { ) }\end{array}$ & $\begin{array}{c}\text { Final ratio } \\
\text { males:females }\end{array}$ & $\begin{array}{c}* \text { Survival } \\
(\%)\end{array}$ & $\begin{array}{c}\text { Final } \\
\text { weight }(\mathrm{g})\end{array}$ & $\begin{array}{c}\text { Estimated } \\
\text { yield }\left(\mathrm{g} \mathrm{m}^{-2}\right)\end{array}$ & FCR & $\begin{array}{c}\text { Growth rate } \\
\left(\mathrm{g} \text { week }^{-1}\right)\end{array}$ \\
\hline 1 & P. schmitti (50) & $1.4: 1$ & $72.0^{\mathrm{a}}$ & $2.8^{\mathrm{a}}$ & $101.54^{\mathrm{a}}$ & $11.5^{\mathrm{a}}$ & $0.12^{\mathrm{a}}$ \\
\hline 2 & P. vannamei (50) & $0.9: 1$ & $88.0^{\mathrm{a}}$ & $10.4^{\mathrm{b}}$ & $458.49^{b}$ & $3.4^{\mathrm{b}}$ & $1.02^{\mathrm{b}}$ \\
\hline 3 & P. schmitti (30) & $0.6: 1$ & $73.3^{\mathrm{a}}$ & $3.2^{\mathrm{a}}$ & $69.36^{\mathrm{a}}$ & $10.3^{\mathrm{a}}$ & $0.13^{\mathrm{a}}$ \\
\hline 4 & P. vannamei (30) & $0.7: 1$ & $90.0^{\mathrm{a}}$ & $10.7^{b}$ & $288.42^{b}$ & $3.4^{\mathrm{b}}$ & $1.02^{\mathrm{b}}$ \\
\hline 5 & $\begin{array}{l}\text { P. schmitti (30) } \\
\text { (mixed, with food) }\end{array}$ & $1.3: 1$ & $93.3^{\mathrm{a}}$ & $2.6^{\mathrm{a}}$ & $36.84^{\mathrm{a}}$ & 8.5 & $0.11^{\mathrm{a}}$ \\
\hline 6 & $\begin{array}{l}\text { P. vannamei (30) } \\
\text { (mixed, with food) }\end{array}$ & $2.0: 1$ & $100^{\mathrm{a}}$ & $11.9^{b}$ & $178.96^{\mathrm{b}}$ & & $1.21^{\mathrm{b}}$ \\
\hline
\end{tabular}

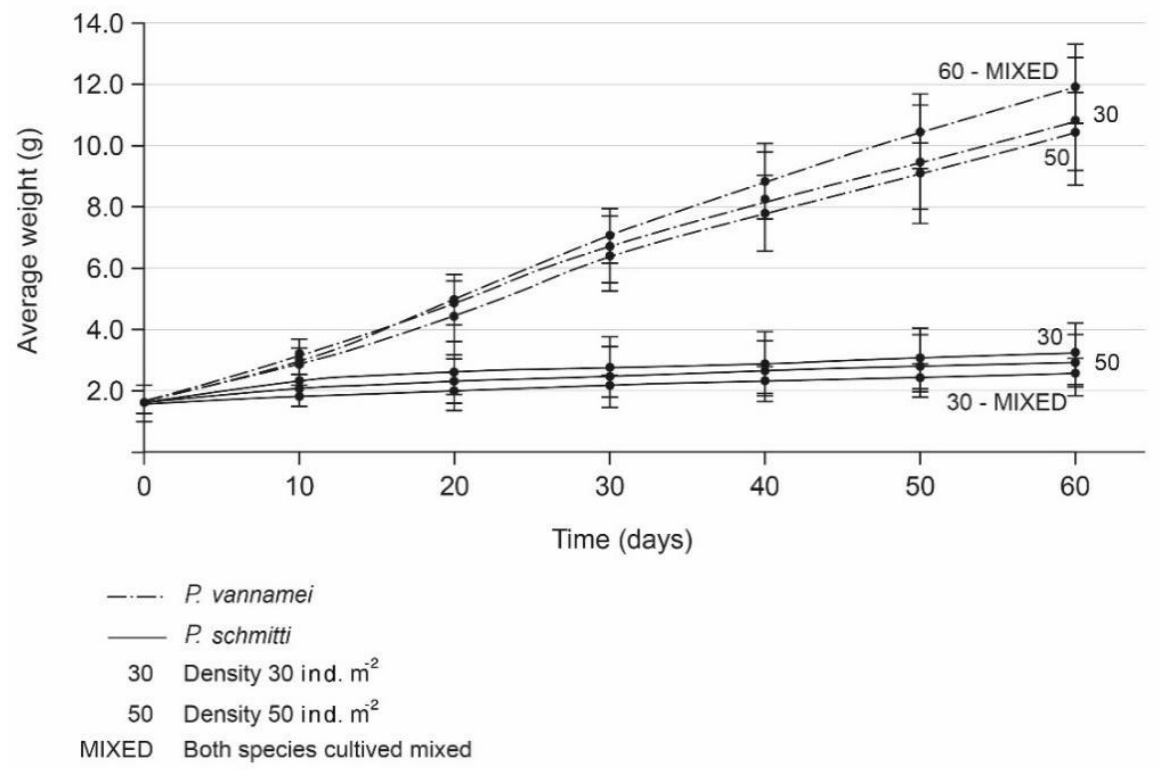

Figure 2. Average decennial growth (mean \pm standard deviation) of Penaeus schmitti and P. vannamei shrimp for 60 days (all treatments with food) at densities of 30 ind $\mathrm{m}^{-2}$ y 50 ind m $\mathrm{m}^{-2}$ (both species isolated or confined together).

average weekly weight even decreased due to the extreme conditions of the test (fasting).

\section{Frequency of molting}

A piece of interesting information can be obtained when the data on molting events is crossed with the lunar cycle during the experimental period. The mean number of exuviae per animal collected was higher in the monoculture treatments, both at 30 and 50 ind $\mathrm{m}^{-2}$ than in the mixed treatment (with food). In the mixed treatment with no food provided, molts were consumed by the starving animals precluding any analysis.

Overall, we observed a coincidence of the "peaks" of the number of daily exuviae collected with changes in the lunar phase (Fig. 4). As shown in the figure, during the first month of the experiment, the number of exuviae collected was higher in $P$. vannamei than in $P$. schmitti. However, considering the total number of exuviae collected, there were no significant differences between $P$. schmitti and $P$. vannamei (ANOVA; $P<$ $0.05)$.

\section{Observed morphological differences}

At the beginning of the experiment, it was difficult to differentiate the specimens of the native species and the exotic species by their external characteristics. With the daily observation of the shrimp, the differences described became more conspicuous. The main morphological differences are the form and size of the hepatopancreas, and the diameter, color, and degree of intesti- 


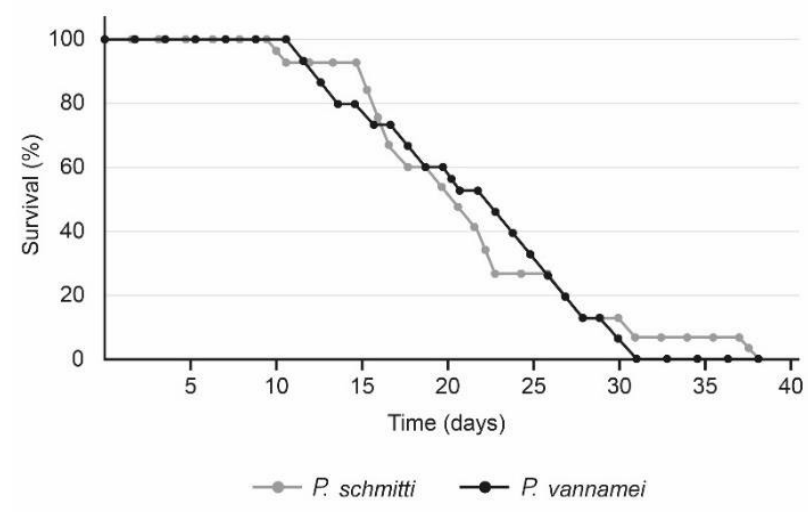

Figure 3. Total survival in 38 days in the five tanks where juveniles of the species Penaeus schmitti and P. vannamei were confined and fasted. Stocking density: 30 ind $\mathrm{m}^{-2}$ (3 individuals of each species per tank).

nal fullness. However, several other subtle external differences can be established where they were confined together (Figs. 5-6).

In Figure 7, it is shown the results of regression analysis between the mean hepatopancreas weight and the total specimen weight for both species. The regression equations for $P$. schmitti and $P$. vannamei corresponded to $\mathrm{y}=0.0316 \mathrm{x}-0.0008$ and $\mathrm{y}=0.0363 \mathrm{x}$ +0.0411 , respectively. The results for $P$. vannamei hepatopancreas were significantly different from $P$. schmitti, demonstrating that this organ is generally bigger in the former species (ANOVA; $P<0.05$ ).

The mean diameter of the fecal threads obtained was $664 \pm 71 \mu \mathrm{m}$ for $P$. vannamei, and $544 \pm 35 \mu \mathrm{m}$ for $P$. schmitti. The comparison between the mean diameter of the fecal threads in shrimps of both species with a total length between 60 and $100 \mathrm{~mm}$ showed that $P$. vannamei intestine was $23 \%$ thicker than that of $P$. schmitti.

\section{DISCUSSION}

During the experiment, the main physical and chemical variables recorded remained within the recommended values for shrimp cultivation (Fenucci, 1988). Furthermore, variables such as temperature, salinity, dissolved oxygen, and total ammonium did not present significant differences $(P<0.05)$ among treatments, probably due to the high rate of daily water exchange (50-75\%). As the water collected by the hatchery's inlet pipes present known oceanic conditions, the variables of water contributed to standardizing the experimental conditions. On the other hand, differences in other variables such as $\mathrm{pH}$ and nitrite in the different treatments may be explained by the amount of organic matter present in the water.
For example, in the tanks with Penaeus vannamei, which contained up to 10 individuals of $10.7 \mathrm{~g}$ average weight, receiving $6.2 \mathrm{~g}$ of food per day, it was observed $\mathrm{pH}$ decrease if compared with the fasting treatment water completely clear (in the absence of food and almost also of wastes), where $\mathrm{pH}$ was significantly more alkaline (8.06), although within the normal range for cultivation. Nitrite reached $0.56 \mathrm{mg} \mathrm{L}^{-1} \mathrm{~N}^{-\mathrm{NO}_{2}}{ }^{-}$in the mixed fasting treatment, but this concentration is much lower than what considered unsafe for the cultivation of another species of penaeid, $F$. paulensis, of $2.55 \mathrm{mg} \mathrm{L}^{-1} \mathrm{NO}_{2}^{-}$(Wasielesky et al., 2017). However, the fact that this treatment lasted much less time (38 days to the harvest of the last tank) than the other five treatments (60 days), evidently also affected this comparison.

The final biomass in the tanks with $P$. vannamei, stocked at the density of 50 ind $\mathrm{m}^{-2}$, reached $91.7 \mathrm{~g}$ (equivalent to $460 \mathrm{~g} \mathrm{~m}^{-2}$ ), while in tanks with Penaeus schmitti, stocked at the same density, biomass was 20.3 $\mathrm{g}$ (equivalent to $100 \mathrm{~g} \mathrm{~m}^{-2}, 4.6$ times lower).

The higher weight gain observed for $P$. vanname $i$ is probably due to the high degree of domestication of this species, as it appeared to adapt to the experimental conditions immediately. However, the fact that it did not differ significantly from that of $P$. schmitti may indicate that these conditions were adequate even for the less domesticated species. This species has been the target of an intense selective breeding process through genetic crosses for decades, which undoubtedly contributed to the high tolerance to live and grow at high stocking densities (Argue et al., 2002; Aungsuchawan et al., 2008; Castillo-Juárez et al., 2015).

On top of that, the species has been adapted to eat the specially formulated feed. For that reason, in the comparison of the growth of $P$. vannamei with the native species, $F$. paulensis carried out by Peixoto et al. (2003), to avoid possible inequalities, besides the pelletized food they included a fresh frozen mixture.

The adaptive feature mentioned above was observed as under the conditions described and with the food supplied, as $P$. vannamei showed the same growth rate $\left(1.0 \mathrm{~g} \mathrm{week}^{-1}\right)$ for both densities. Even though the mean weekly weight increment observed in our experiment was lower than reported for $P$. vannamei shrimp by the literature. For example, Briggs et al., (2004), FungeSmith \& Briggs (2005) and Wyban (2007) reported a growth rate between 1.0-1.7 $\mathrm{g}^{\text {week }}{ }^{-1}$ for $P$. vannamei commercial crops in Asian countries. Moreover, Samadan et al. (2018), obtained growths of 0.86 and $0.78 \mathrm{~g} \mathrm{week}^{-1}$, but at stocking densities as high as 200 and 300 ind $\mathrm{m}^{-2}$, respectively. 


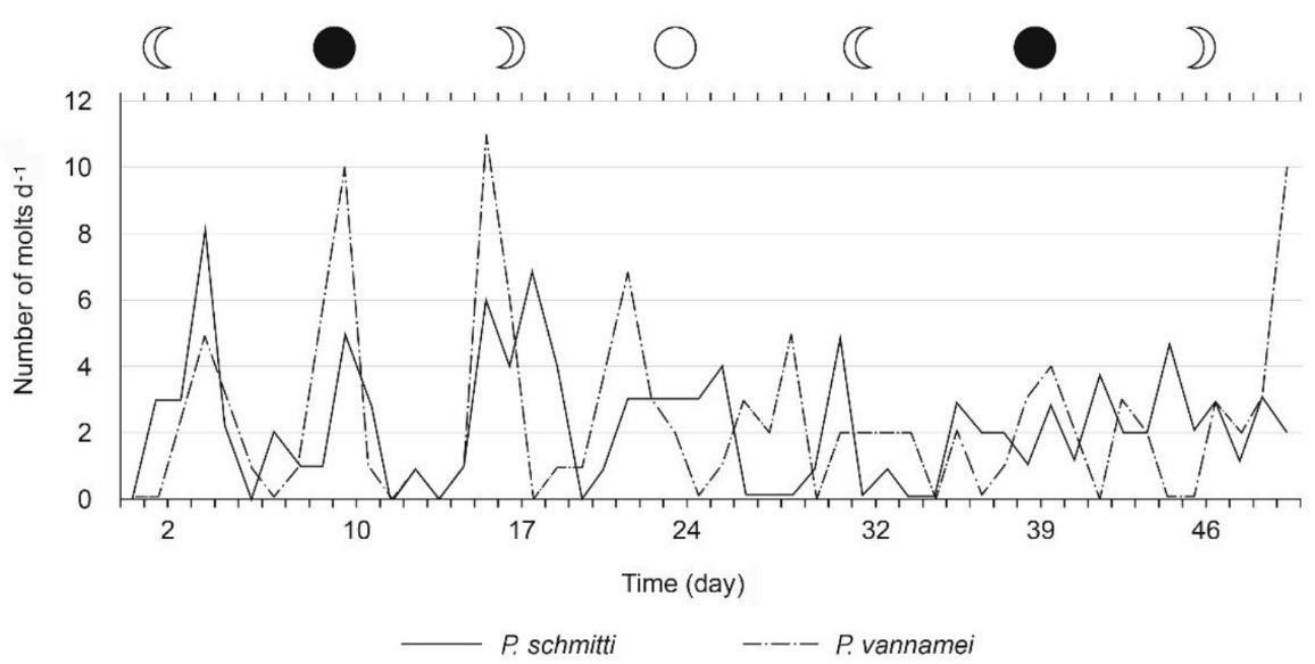

Figure 4. The total number of molts registered daily, in the treatments with Penaeus schmitti and P. vannamei (with a stocking density of 50 ind $\mathrm{m}^{-2}$ ) and lunar phases in the period.

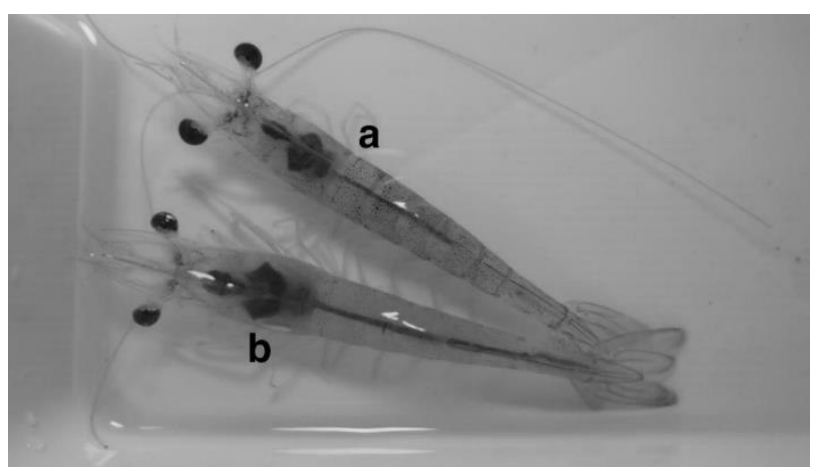

Figure 5. a) Penaeus schmitti specimen, b) P. vannamei specimen. Note the differences in the shape and size of the hepatopancreas and the thickness of the intestine. Photo: C. Tavares (2017).

The growth rate is a determinant factor in the cultivation of any species, so this variable was analyzed for $P$. schmitti in several studies. In this study, the growth rates in the treatments with $P$. schmitti averaged $0.1 \mathrm{~g}$ week $^{-1}, 10$ times lower than what was observed for $P$. vannamei. Several factors may explain this but, most importantly, these are wild animals without any family selection or domestication, which have been maintained in containers without shelter, with transparent water and formulated feed as the only food source.

However, it is important to note that this growth rate was exceedingly low even if we consider the species. In comparison, Fernández de Alaiza et al. (1994b), reported growths of 0.6-0.8 $\mathrm{g}^{\text {week }}{ }^{-1}$ with this species in Santa Cruz del Sur, Cuba, in earthen ponds stocked at 17-20 ind $\mathrm{m}^{-2}$. Likewise, Artiles (2002), compa-ring crops of this species at densities of 25, 50, and 75 ind $\mathrm{m}^{-2}$ in Yaguanabo, Cuba, reported a weekly growth of $0.6 \mathrm{~g}$ week $^{-1}$ for all ponds in 120 days. On the other hand, Fraga et al. (2002), reported growths of between 0.4 and $1.0 \mathrm{~g}^{-1}$ week $^{-1}$ in experimental pens within earthen ponds in Tunas da Zaza, Cuba, stocked at densities between 10 and 25 ind $\mathrm{m}^{-2}$. Studying the abundance of zoobenthos in this experiment, these authors estimated a contribution of natural food to the P. schmitti growth of $58.2-87.9 \%$, in the tested treatments. Likewise, they reported a potential growth of $22.7 \mathrm{~g}$, achieved by specimens of the species in a 72day period, which had been stocked at 1 ind $\mathrm{m}^{-2}$ and consumed only natural food.

On the other hand, $P$. schmitti production data published by Allessi (2000), indicate that commercial ponds stocked at a mean density of $13.9 \mathrm{PL} \mathrm{m}^{-2}$ in Paranaguá (PR), Brazil, grew at a mean of $0.6 \mathrm{~g} \mathrm{week}^{-1}$. The great influence of stocking density on $P$. schmitti growth was later corroborated by Marquez et al. (2012) in Santa Catarina, Brazil, who compared crops in fiberglass tanks (with a phytoplankton bloom), stocked at 8,20 and 50 ind $\mathrm{m}^{-2}$, and obtained growths of 0.5 , 0.3 , and $0.4 \mathrm{~g}^{\text {week }}{ }^{-1}$, respectively, in 105 days. These authors also agree that high stocking densities affect growth (possibly by spatial competition and lack of natural food), obtaining the best result with the density of 8 ind $\mathrm{m}^{-2}$, even with an average temperature of $24.6^{\circ} \mathrm{C}$, which they considered low for the species.

On the other hand, Castilho-Barros et al. (2014) and Henriques et al. (2014), in experiments to obtain $P$. schmitti shrimp for live bait, reported yield or productivity averages between 591 and $831 \mathrm{~g} \mathrm{~m}^{-2}$. These values are 5 to 22 times higher than those obtained 

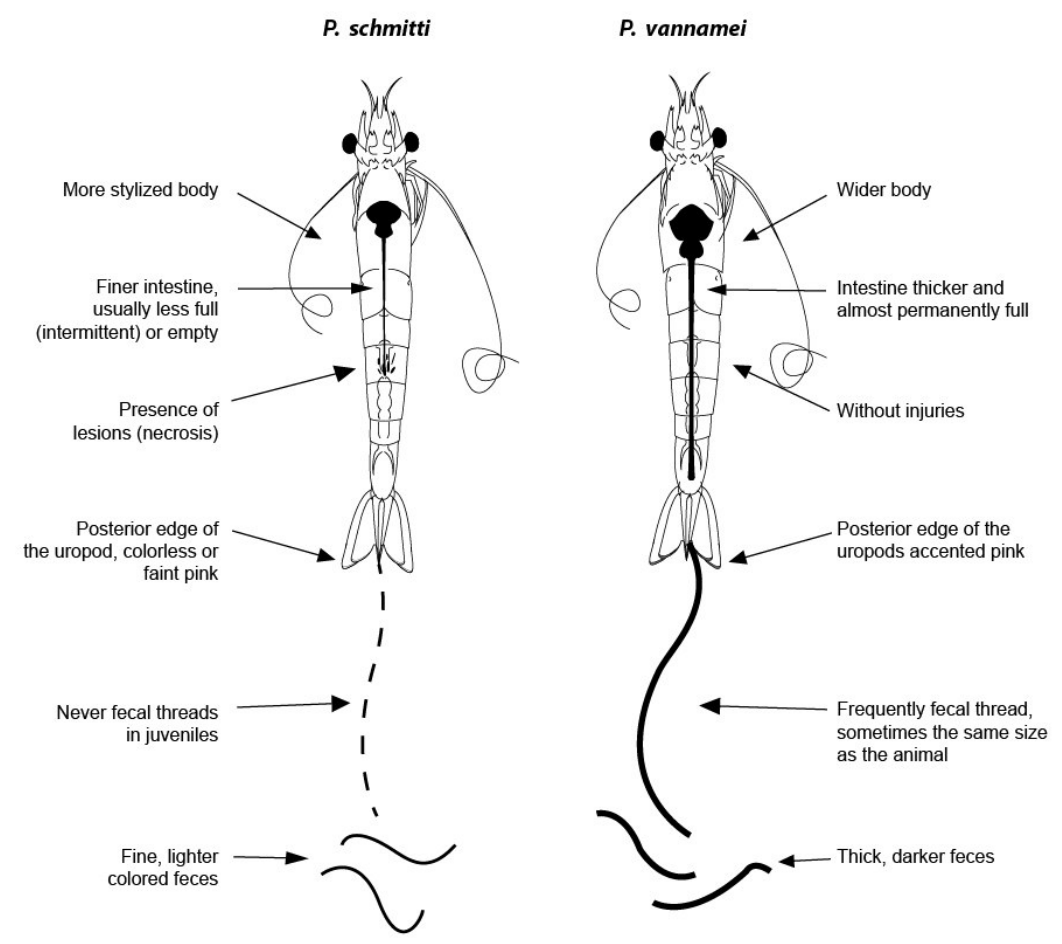

Figure 6. Main morphological differences observed in live shrimps of Penaeus schmitti and P. vannamei species. Illustration by R.F. de Alaiza Amador (2018).

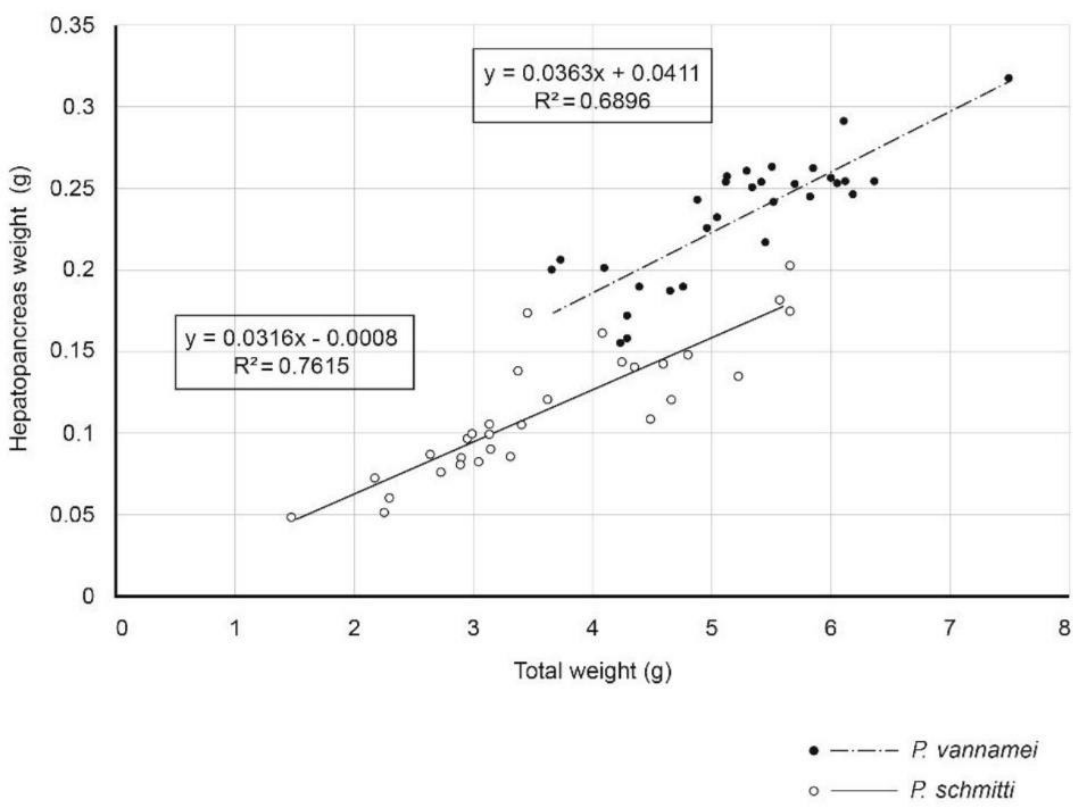

Figure 7. Regression between hepatopancreas weight and the total weight of Penaeus schmitti and P. vannamei $(\mathrm{n}=30$, for both species).

in our work with the same species, mainly due to the high stocking densities used by these authors (from 151.5 to 208.3 ind $\mathrm{m}^{-2}$ ), to obtain a higher amount of juveniles.
Another aspect that influences shrimp growth is the molting frequency. Bonilla-Gómez et al. (2013) compared the molting frequency and other physiological indicators in Farfantepenaeus duorarum, finding 
that the protein concentration in the cultivated animals was significantly higher than that of the wild shrimps of this species. In the case of the experiment reported here, the molting frequency was not a significant element in the comparison of species, but as already mentioned, the difference in the degree of domestication does seem to have had a significant influence.

In this study, the growth observed for P. vannamei, when cultivated together with $P$. schmitti, was higher than in monoculture. These results do not coincide with that reported by Martínez-Cordova \& Peña-Messina (2005); in their work, they reported a higher growth of $P$. vannamei in monoculture than when cultivated with blue shrimp, Penaeus stylirostris.

The 60 days duration of the experiment, could lead us to ask: what would the growth of $P$. schmitti be like if the experiment had continued, for example, twice as long? To answer this question, we should refer to the work already mentioned by Allessi (2000). Although the author has relied on commercial crop data, her comparison of the growth of $P$. schmitti and $P$. vannamei may provide information of interest. For $P$. schmitti, the average weight reported after 60 days of cultivation was approximately $1.5 \mathrm{~g}$ and at 120 days of $7.3 \mathrm{~g}$. In that same period, the average weight of $P$. vanname $i$ was 9.4 and $13.4 \mathrm{~g}$, respectively. It should be noted that even though the final mean weight of $P$. vannamei in this work was almost twice that of $P$. schmitti at the harvest, several factors favored the exotic species. Among them, differences in earthen ponds conditions, type of food, and use of partial harvests.

The observation of the interaction between tested shrimp species during the experiment in mixed treatment revealed some interesting information. The conditions of the aquariums (rectangular plastic boxes, with white background) facilitated this type of observation.

In terms of agonistic behavior, no signs of increased aggressiveness by the presence of both species in the same tank were observed compared to what was observed in monoculture treatments.

Even though $P$. schmitti demonstrated a much more nervous attitude at all times, many jumps and blows against the walls were detected, in monoculture, especially during siphoning (tank cleaning). Occasionally they were able to jump out of the water and fall to the ground. For this reason, P. schmitti specimens were frequently seen with melanized cuticular lesions on the dorsal part of the abdomen.

On the contrary, in monoculture treatment tanks with $P$. vannamei, the specimens were much quieter and less prone to jump. Due to $P$. vannamei relative docility, they generally did not stir even during the cleaning of the boxes. In mixed treatment, $P$. vannamei's docility habits were sometimes negatively affected by the "nervousness" of $P$. schmitti. When the shrimp of the species $P$. schmitti jumped, a few shrimp of the P. vannamei species also jumped in reaction.

In mixed treatment with feeding, $P$. vanname $i$ specimens always showed a much higher voracity and interest in the provided food than $P$. schmitti specimens did. Therefore, almost whenever observed, the $P$. vannamei shrimp had a full digestive tract.

During all-time in the feeding treatments, both mixed and monoculture, it was possible to spot the presence of exuviae. However, even during this extremely vulnerable situation, no overall mortality was recorded. In the mixed treatment with food, animals of both species prioritized the consumption of artificial food. In four of the five replicates of this treatment, no animal of any of the two species died.

The possibility of the establishment of a reproductive population in the coastal areas where the natural populations of $P$. schmitti are distributed is one of the most worrisome potential environmental impacts that can be determined by the escape of P. vannamei from farms. As it is well known, in the extensive coastal areas naturally inhabited by $P$. schmitti, hundreds of shrimp farms cultivating $P$. vannamei operate. There are numerous reports of the presence of $P$. vannamei in natural areas where it is considered an exotic species, from Brazil (Santos \& Coelho, 2002; Barbieri \& Melo, 2006; Loebmann et al., 2010; Barbieri et al., 2016b), USA (Balboa et al., 1991), Mexico (Wakida-Kusunoki et al., 2011), Thailand (Senanan et al., 2007) and others. Also, this species is marketed as live bait in northeastern Brazil (Leão et al., 2011), so there is a permanent risk of its dissemination in the natural environment.

The external differences reported here could be useful for the preliminary identification of specimens of both species. For more precise identification, the PCR method described by Vilasboa et al. (2018) could also be considered.

Some of the most interesting results of this study came from the interaction between both species when cultivated at relatively high densities. As mentioned, at the end of the experiment, the final mean weight of $P$. vannamei cultured together with the native species was even higher than the one obtained in the monoculture treatments.

We believe that two aspects could be involved: $P$. vannamei species are markedly voracious, and in this case, they had more food available, calculated for them, and corresponding to the specimens of P. schmitti, 
which always showed less interest in the food. Being distinct, confined species, it seems that interspecific competition occurs and, consequently, a greater difference in size. The result of this coexistence, in terms of growth, was beneficial for $P$. vannamei (which reached a higher average weight) and harmful for $P$. schmitti.

Even being much larger, when food was supplied, $P$. vannamei did not attack $P$. schmitti. At first, this behavior might seem understandable, as the specimens of the two species were about the same size. However, at the end of the experiment, when the P. vannamei shrimp reached an average weight 4.5 times higher than those of P. schmitti (Fig. 2, both named as "mixed"), the high survival rate was also maintained.

Martínez-Cordova \& Peña-Messina (2005), have already highlighted the greater voracity of $P$. vanname $i$ (also expressed in a higher rate of stomach fullness) compared to $P$. stylirostris. Subsequently, Chavanich et al. (2016) compared the food intake of $P$. vannamei with that of five species of Asian penaeid shrimp, finding that this species proved to be more voracious than these native species, among them Penaeus monodon. It does seem to indicate that in the future (and hypothetical) coexistence of both species in the natural environment, with enough food resources, interspecific competition would tend to be lower. Could this data be extended to their behavior in nature?

Intraspecific interactions of wild and cultivated Penaeus plebejus shrimp were studied to determine the differential effect of food and shelter limitations on the survival of both groups (Ochwada-Doyle et al., 2012). These authors emphasized the importance of the refuge, in that case, macroalgae, to carry out repopulations in natural areas of Australia. Those results, referring to the interaction of cultivated and wild animals of the same species, draws attention to the complexity of this type of behavioral studies, which can subsidize information about possible impacts of an exotic species on the natural environment.

In the case of our work, we also compared the species in an "extreme" situation, with wild shrimp confined together with farmed shrimp from a nonnative species in the absence of shelter and food. In this case, the "domesticated" P. vannamei specimens proved to be as capable of defending themselves (with depredation/cannibalism) as the "wild" P. schmitti. With final weights averaging $1.3 \mathrm{~g}$ for $P$. schmitti and $1.5 \mathrm{~g}$ for L. vannamei, both species were about the same size, which makes sense that no species have prevailed in this treatment.

Throughout the above, it would be necessary and opportune to continue and extend this research to include another aspect of this interaction. Loebmann $e t$ al. (2010), pointed out the coincidence in habitat and food between $P$. vannamei and native species such as $P$. schmitti, as well as the possibility of transmission of viral diseases that already affected the exotic species in captivity. On the other hand, Balboa et al. (1991) have recommended the study of competition and disease transmission as possible ecological interactions of $P$. vannamei with populations of native species. The Taura syndrome virus, which caused significant losses to shrimp farming on a global scale, has already been detected in wild populations of $P$. schmitti in Venezuela (Fajardo et al., 2010).

Additionally, in accord to the personal communication of fishermen who commercialize both species as live bait for sport fishing in the state of Paraná, Brazil: "P. vannamei does not represent any risk in the natural environment, since, they are more domesticated animals, shrimps do not have reflexes of escapedefense and are easily depredated." The results presented here contradict the above and indicate the need for these studies and even greater environmental control.

The results of this work reaffirm the zootechnical advantages of $P$. vannamei for commercial shrimp farming, already shown in several previous studies. Its cultivation is generally carried out by large, wellestablished companies, and it is recognizable as a jobcreating economic activity, especially important in the tropical belt of the world. The global production of this species in 2016 was approximately 3.0 million tonnes, generating more than USD 18 billion (Jory, 2017).

With all the economic aspects considered, it is also vastly known that the introduction of this exotic species may lead to the several environmental problems, such as genetic pollution and spread of diseases to natural stocks, producing considerable economic losses and social affections (FAO, 2013; Fernández de Alaiza et al., 2018).

Based on these facts, several studies have highlighted the potential of the cultivation of native species and recommended their study and use, especially when social and environmental values are considered (Henriques et al., 2014; Occhi et al., 2017). We consider that the major potential of $P$. schmitti at present is for low density cultivation of organic crops in coastal lagoons, aiming niche markets. Also, as demonstrated by Preto et al. (2009) with $F$. paulensis, the production of live bait for the sport fishing and stock repopulation to subsidize artisanal fishing, and others end mostly linked to coastal communities. The benefits P. schmitti "domestication" would be the establishment of broodstock, genetic improvement, and the development of formulated feeds related to the requirements of this native species, which could contribute significantly to the improvement of its zootechnical performance. 
We consider that the results obtained by this work could significantly contribute to information of interest for this important subject.

\section{ACKNOWLEDGMENTS}

The authors are grateful for the support provided by the Center for Marine Aquaculture and Repopulation, from the Integrated Group of Aquaculture and Environmental Studies (CAMAR - GIA), Federal University of Paraná, PR, Brazil; by Mr. Antonio Sergio Borges and Mr. Sergio Roberto Pits; and the helpful suggestions of Dr. Silvio Peixoto and Dra. Setuko Masunari. We also thank Silvia Amador P., Camila P. Tavares, Jorge de Freitas, Alaércio Freitague and Jovane Carraro for their assistance during the preparation and execution of the experimental work; to Rafael Fernández de Alaiza Amador for the digitalization of the images and to Silvia Fernández de Alaiza for the language revision of the manuscript. Rafael Fernández de Alaiza G.M. holds a Ph.D. fellowship from CNPq (Brazilian National Research Council, Brazil) at UFPR (Federal University of Parana, Brazil). Ubiratã A.T. da Silva and Eduardo L.C. Ballester are research fellowship recipients from CNPq.

\section{REFERENCES}

American Public Health Association (APHA). 1995. Standard methods for the examination of water and wastewater. American Public Health Association Inc., New York.

American Public Health Association (APHA). 2005. Standard methods for the examination of water and wastewater. American Public Health Association/ American Water Works Association/Water Environment Federation, Washington DC.

Allessi, F.E. 2000. Avaliação dos principais índices zootécnicos e ambientais envolvidos na produção comercial de Litopenaeus vannamei e uma análise comparativa com as espécies nativas do litoral paranaense: Farfantepenaeus paulensis e L. schmitti. Tese de Mestrado, Universidade Federal do Paraná, Paraná, 64 pp.

Álvarez, C.J.S. 2007. Sustitución de harina de pescado por harina de soya e inclusión de aditivos en el alimento a fin de mejorar la engorda del camarón blanco Litopenaeus schmitti. Tesis de Doctor en Ciencias del Uso, Manejo y Preservación de los Recursos Naturales (Orientación en Acuacultura), Centro de Investigaciones Biológicas del Noroeste, Baja California Sur.
Andrade, G. \& Pérez, E. 2004. Age and growth of the white shrimp Litopenaeus schmitti in western Venezuela. Interciencia, 29: 212-218.

Andrade, G. \& Pérez, E. 2007. Comparación de métodos de estimación de parámetros de crecimiento del camarón blanco Litopenaeus schmitti en el occidente de Venezuela. Interciencia, 32: 35-40.

Arenal, A., Pimentel, R., Pimentel, E. \& Aleström, P. 2008. Growth enhancement of shrimp (Litopenaeus schmitti) after the transfer of tilapia growth hormone gene. Biotechnology Letters, 30: 845-851.

Argue, B.J., Arce, S.M., Lotz, J.M. \& Moss, S.M. 2002. Selective breeding of Pacific white shrimp (Litopenaeus vannamei) for growth and resistance to Taura syndrome virus. Aquaculture, 204: 447-460.

Artiles, M.A. 2002. Cultivo intensivo de camarón blanco (Litopenaeus schmitti) bajo diferentes densidades de siembra. Boletín del Centro de Investigaciones Biológicas, Universidad del Zulia, 36: 1-11.

Arzola, G.J.F., Flores, C.L.M., Izabal, C.A. \& Gutiérrez, R.Y. 2008. Crecimiento de camarón blanco (Litopenaeus vannamei) en un estanque rústico a baja salinidad. Revista AquaTIC, 28: 8-15.

Aungsuchawan, S., Ball, A.O., Chapman, R.W., Shepard, E., Browdy, C. \& Withyachumnarnkul, B. 2008. Evaluation of published microsatellites for paternity analysis in the Pacific white shrimp Litopenaeus vannamei. ScienceAsia, 34: 115-118.

Balboa, W.A., King, T.L. \& Hammerschmidt, P.C. 1991. Occurrence of Pacific white shrimp in Lower Laguna Madre, Texas. Proceedings of the Annual Conference Southeast Association Fish and Wildlife Agencies, 45: 288-292.

Barbieri, E. 2010. Acute toxicity of ammonia in white shrimp (Litopenaeus schmitti) (Burkenroad, 1936, Crustacea) at different salinity levels. Aquaculture, 306: 329-333.

Barbieri, E. \& Melo, G.A.S. 2006. Biodiversidade: ocorrência da espécie exótica Litopenaeus vannamei (Boone, 1931) no complexo estuarino-lagunar de Cananéia-Iguape-Ilha Comprida. O Mundo da Saúde, 30: 654-659.

Barbieri, E., Coa, F. \& Rezende, K.F.O. 2016b. The exotic species Litopenaeus vannamei (Boone, 1931) occurrence in Cananeia, Iguape and ilha Comprida Lagoon Estuary Complex. Boletim do Instituto de Pesca, 42: 479-485.

Barbieri, E., Bondioli, A.C.V., Melo, C.B. \& Henriques, M.B. 2016a. Nitrite toxicity to Litopenaeus schmitti (Burkenroad, 1936, Crustacea) at different salinity levels. Aquaculture Research, 47: 1260-1268.

Bonilla-Gómez, J.L., Chiappa-Carrara, X., Galindo, C., Cuzón, G. \& Gaxiola, G. 2013. Effects of adaptation 
to laboratory conditions on growth, molting, and food consumption of juvenile Farfantepenaeus duorarum (Decapoda: Penaeidae). Journal of Crustacean Biology, 33: 191-197.

Boone, L. 1931. Anomuran, Macruran Crustacea from Panama and Canal Zone. Bulletin of the American Museum of Natural History, 63: 137-189.

Briggs, M., Funge-Smith, S., Subasinghe, R.P. \& Phillips, M. 2004. Introductions and movement of two penaeid shrimp species in Asia and the Pacific. FAO Fisheries Technical Paper, RAP Publication 2004/10, 476: 87 pp.

Brito, L.O., Arantes, R., Magnotti, C., Derner, R., Pchara, F., Olivera, A. \& Vinatea, L. 2014. Water quality and growth of Pacific white shrimp Litopenaeus vannamei (Boone) in co-culture with green seaweed Ulva lactuca (Linnaeus) in the intensive system. Aquaculture International, 22: 497-508.

Burkenroad, M.D. 1936. A new species of Penaeus from the American Atlantic. Anais da Academia Brasileira de Ciencias, 8: 315-318.

Carvalho, C.D. 2013. Crescimento e mortalidade do camarão branco Litopenaeus schmitti (Burkenroad, 1936) (Crustacea: Decapoda: Penaeidae) em ambiente natural e em confinamento. Tese de Mestrado, Universidade Federal Rural do Rio de Janeiro, Rio de Janeiro, 90 pp.

Castilho-Barros, L., Barreto, O.S. \& Henriques, M.B. 2014. The economic viability for the production of live baits of white shrimp (Litopenaeus schmitti) in recirculation culture system. Aquaculture International, 22(3).

Castillo-Juárez, H., Campos-Montes, G.R., CaballeroZamora, A. \& Montaldo, H.H. 2015. Genetic improvement of Pacific white shrimp [Penaeus (Litopenaeus) vannamei]: perspectives for genomic selection. Frontiers in Genetics, 6: 93.

Chavanich, S., Viyakarn, V., Senanan, W. \& Panutrakul, S. 2016. Laboratory assessment of feeding-behavior interactions between the introduced Pacific white shrimp Litopenaeus vannamei (Boone, 1931) (Penaeidae) and five native shrimps plus a crab species in Thailand. Aquatic Invasions, 11: 67-74.

De Barros, L.C., Barreto, O.J.S. \& Henriques, M.B. 2014. The economic viability for the production of live baits of white shrimp (Litopenaeus schmitti) in recirculation culture system. Aquaculture International, 22: 19251935.

Food and Agriculture Organization (FAO). 2013. Report of the FAO/MARD Technical Workshop on Early Mortality Syndrome (EMS) or Acute Hepatopancreatic Necrosis Syndrome (AHPNS) of cultured shrimp (under TCP/VIE/3304). Fisheries and Aquaculture Report, FAO, Rome.
Fajardo, C., Rodulfo, H., De Donato, M., Manrique, R., Boada, M. \& Aguado-García, N. 2010. Detección molecular del virus del síndrome del Taura en Litopenaeus schmitti silvestres del lago de Maracaibo y la laguna de Unare, Venezuela. Revista Científica, 20(5): 457-466.

Fenucci, J. 1988. Manual para la cría de camarones peneidos. Programa Cooperativo Gubernamental FAO, Brasilia, GCP/RLA.075/ITA: 8 pp.

Fernández de Alaiza, R. \& Jaime-Ceballos, B. 1990. Producción intensiva de juveniles de camarón Penaeus schmitti en tanques de concreto de $30 \mathrm{~m}^{2}$. Revista Pesca al Día, 92: 12-23.

Fernández de Alaiza, R., Funes, H. \& Zaragoza, I. 1994a. Engorde intensivo de camarón blanco $P$. schmitti en estanques de 2.5 ha con aireación por paletas. Revista Cubana de Investigaciones Pesqueras, 18: 20-24.

Fernández de Alaiza, R., Jaime-Ceballos, B. \& SosaRodríguez, R. 1994b. Engorde intensivo del camarón P. schmitti en Santa Cruz del Sur, Cuba. Revista de Investigaciones Marinas, 15: 157-163.

Fernández de Alaiza, R., Silva, U.d.A.T., Tavares, C.P.d.S. \& Ballester, E.L.C. 2018. Use of native and non-native shrimp (Penaeidae, Dendrobranchiata) in world shrimp farming. Reviews in Aquaculture, 10: 899-912.

Fóes, G., Krummenauer, D., Lara G., Poersch, L. \& Wasielesky, W. 2016. Long term storage and the compensatory growth of white shrimp Litopenaeus vannamei in aquaculture ponds. Latin American Journal of Aquatic Research, 44: 588-594.

Food and Agriculture Organization (FAO). 2016. Species fact sheets. Penaeus schmitti (Burkenroad, 1936). FAO, Rome.

Fraga-Castro, I. \& Jaime-Ceballos, B. 2011. Estrategias para optimizar el manejo del alimento en el engorde del camarón blanco del Caribe Litopenaeus schmitti. Revista AquaTIC, 35: 20-34.

Fraga, I., Galindo, J., de Arazoza, M. \& Sánchez, A. 2002. Evaluación de niveles de proteína y densidades de siembra en el crecimiento del camarón blanco Litopenaeus schmitti. Revista de Investigaciones Marinas, 23(2): 141-147.

Fugimura, M.M.S. 2009. Efeito da temperatura e densidade de estocagem no crescimento e sobrevivência de juvenis de Litopenaeus schmitti. Dissertação (Mestrado), Programa de Pós-Graduação em Zootecnia, Universidade Federal Rural do Rio de Janeiro, Rio de Janeiro.

Funge-Smith, S. \& Briggs, M. 2005. The introduction of Penaeus vannamei and P. stylirostris into the AsiaPacific region. FAO Conference Proceedings, Internatio- 
nal mechanisms for the control and responsible use of alien species in aquatic ecosystems. FAO, Rome, 149167.

Galindo-López, J. 2009. Aproximación a los requerimientos nutricionales de juveniles de camarón blanco Penaeus schmitti: evaluación de niveles y fuentes de proteína en la dieta. Tesis de Título de Maestro en Ciencias, Universidad de la Habana, La Habana.

Gassman, J. \& Rojas, H.L. 2016. Biología y pesquería del camarón Litopenaeus schmitti en la Laguna de Tacarigua, Venezuela. Revista de Biología Marina y Oceanografía, 51: 655-663.

Girotto, M.V.F. 2010. Efeitos da amônia sobre juvenis de Litopenaeus vannamei (Boone, 1931) e Litopenaeus schmitti (Burkenroad, 1936): excreção e toxicidade. Dissertação de Mestrado em Ciências Veterinárias, Universidade Federal do Paraná, Curitiba.

Hammer, Ø., Harper, D.A.T. \& Ryan, P.D. 2001. PAST: Paleontological Statistics Software Package for Education and Data Analysis. Palaeontologia Electronica 4(1): 9 pp.

Henriques, M.B., Alves, P.M.F., Barreto, O.J.S. \& Souza, M.R.D. 2014. Growth of Litopenaeus schmitti (Burkenroad, 1936) and Farfantepenaeus paulensis (Pérez-Farfante, 1967) shrimp reared in recirculation culture system. Brazilian Journal of Oceanography, 62: 323-330.

Jaime-Ceballos, B.J. 2006. Evaluación de la harina de Spirulina platensis como alimento y aditivo para la producción de postlarvas de camarón blanco Litopenaeus schmitti (Pérez-Farfante \& Kensley, 1997). Tesis Doctorado en Ciencias en el Uso, Manejo y Preservación de los Recursos Naturales, Centro de Investigaciones Biológicas del Noroeste, Baja California Sur.

Jaime-Ceballos, B. \& Galindo-López, J. 2006. Dietas prácticas para el cultivo de Litopenaeus schmitti: una revisión. Revista Electrónica de Veterinaria, 7: 1-13.

Jory, D. 2017. Estado global, retos y perspectivas de la camaronicultura. Presentación en Aqua Expo 2017. Cámara Nacional de Acuicultura, Guayaquil, 56 pp.

Khanjani, M.H., Sajjadi, M., Alizadeh, M. \& Sourinejad, I. 2016. Nursery performance of Pacific white shrimp (Litopenaeus vannamei Boone, 1931) cultivated in a biofloc system: the effect of adding different carbon sources. Aquaculture Research, 48(4): 1491-1501.

Leão, T.C.C., Almeida, W.R., Dechoum, M. \& Ziller, S.R. 2011. Espécies exóticas invasoras no nordeste do Brasil: contextualização, manejo e políticas públicas. Centro de Pesquisas Ambientais do Nordeste e Instituto Hórus de Desenvolvimento e Conservação Ambiental, Recife.

Loebmann, D., Mai, A.C.G. \& Lee, J.T. 2010. The invasion of five alien species in the Delta do Parnaíba, environmental protection area, northeastern Brazil. Revista de Biología Tropical, 58: 909-923.

Maciel, J.C., Francisco, C.J. \& Miranda-Filho, K.C. 2018. Compensatory growth and feed restriction in marine shrimp production, with emphasis on biofloc technology. Aquaculture International, 26: 203-212.

Márquez, J.E.Q., Andreatta, E.R., Vinatea, L., Olivera, A. \& Brito, L.O. 2012. Efeito da densidade de estocagem nos parâmetros zootécnicos da criação de camarões Litopenaeus schmitti. Boletim do Instituto de Pesca, 35: 39-45.

Martínez-Cordova, L.R. \& Peña-Messina, E.M. 2005. Biotic communities and feeding habits of Litopenaeus vannamei (Boone, 1931) and Litopenaeus stylirostris (Stimpson, 1974) in monoculture and polyculture semi-intensive ponds. Aquaculture Research, 36: 1075-1084.

Occhi, T.V.T., Faria, L. \& Vitule, J.R.S. 2017. Native or non-native? That is the question: a complementary discussion to Saint-Paul (2017). Acta of Fisheries and Aquatic Resources, 5: 12-16.

Ochwada-Doyle, F., Gray, C.A., Loneragan, N.R., Suthers, I.M. \& Taylor, M.D. 2012. Competition between wild and captive-bred Penaeus plebejus and implications for stock enhancement. Marine Ecology Progress Series, 450: 115-129.

Peixoto, S., Wasielesky, W. \& Louzada, L. 2003. Comparative analysis of pink shrimp, Farfantepenaeus paulensis, and Pacific white shrimp, Litopenaeus vannamei, culture in extreme southern Brazil. Journal of Applied Aquaculture, 14: 101-111.

Pérez-Farfante, I. 1970. Synopsis of biological data on the white shrimp Penaeus schmitti Burkenroad, 1936. In: Mistakidis, M.N. (Ed.). Proceedings of the World Scientific Conference on the Biology and Culture of Shrimps and Prawns, Mexico City, 12-21 June 1967. FAO Fisheries Synopsis, 100(4): 1167-1627.

Pérez-Farfante, I. 1988. Illustrated key to Penaeoid shrimps of commerce in the Americas. NOAA/ National Marine Fisheries Service, NOAA Technical Report NMFS, 64: 1-38.

Preto, A.L., Pissetti, T.L., Wasielesky Jr., W., Poersch, L.H. \& Cavalli, R.O. 2009. Production of live baitshrimp (Farfantepenaeus paulensis) in cages at varying stocking densities. Boletim do Instituto de Pesca, 35: 39-45.

Rosas, C., Cuzon, G., Taboada, G., Pascual, C., Gaxiola, G. \& Van Wormhoudt, A. 2001. Effect of dietary protein and energy levels on growth, oxygen consumption, haemolymph, and digestive gland carbohydrates, nitrogen excretion and osmotic pressure of Litopenaeus vannamei (Boone) and $L$. setiferus (Linne) juveniles (Crustacea; Decapoda; Penaeidae). Aquaculture Research, 32: 531-547. 
Samadan, G., Rustadi, R., Djumanto, D. \& Murwantoko, M. 2018. Production performance of whiteleg shrimp Litopenaeus vannamei at different stocking densities reared in sand ponds using plastic mulch. Aquaculture, Aquarium, Conservation \& Legislation - International Journal of the Bioflux Society, 11: 1213-1221.

Santos, C.H.A., Lourenco, J.A., Baptista, R.B. \& Igarashi, M.A. 2009. Crescimento e sobrevivência do camarão branco do Pacífico Litopenaeus vannamei (Boone, 1931) em diferentes salinidades. Ciência Animal Brasileira, 10: 783-789.

Santos, D.B., Barbieri, E., Bondioli, A.C. \& Melo, C.B. 2014. Effects of lead in white shrimp (Litopenaeus schmitti) metabolism regarding salinity. O Mundo da Saúde, 38: 16-23.

Santos, M. 2005. A pratica da carcinicultura de Litopenaeus vannamei (Boone, 1931) (Crustacea, Decapoda, Penaeidae) e suas implicacoes no nordeste do Brasil. Boletim Técnico-Científico do CEPENE, 13: 129-141.

Santos, M. \& Coelho, P.A. 2002. Espécies exóticas de camarões peneídeos (Penaeus monodon Fabricius, 1798 e Litopenaeus vannamei Boone, 1931) nos ambientes estuarino e marinho do nordeste do Brasil. Boletim Técnico Científico do CEPNOR, 10: 209222.

Santos, M., Pereira, J.A., Ivo, C.T.C. \& Souza, R.F.C. 2006. Crescimento do camarão branco, Litopenaeus schmitti (Burkenroad, 1936) (Crustacea, Decapoda, Penaeidae), no nordeste do Brasil. Boletim TécnicoCientífico do CEPENE, 14: 59-70.

Senanan, W., Tangkrock-Olan, N., Panutrakul, S., Barnette, P., Wongwiwatanawute, C., Niphonkit, N. \& Anderson, D.J. 2007. The presence of the Pacific whiteleg shrimp (Litopenaeus vannamei Boone, 1931) in the wild in Thailand. Journal of Shellfish Research, 26: 1187-1192.

Silva, E.F., Calazans, N., Nolé, L., Soares, R., Frédou, F.L. \& Peixoto, S. 2018. Population dynamics of the white shrimp Litopenaeus schmitti (Burkenroad, 1936) on the southern coast of Pernambuco, northeastern Brazil. Journal of the Marine Biological Association of the United Kingdom, 99(2): 429-435.

Received: 3 May 2019; Accepted: 17 December 2019
Sosa, M.B. 2009. Las pesquerías de arrastre de camarón en Cuba. Proyecto FAO: EP/INT/724/GEF. Centro de Investigaciones Pesqueras, La Habana, 43 pp.

Tacon, A.G.J., Cody, J.J., Conquest, L.D., Divakaran, S., Forster, I.P. \& Decamp, O.E. 2002. Effect of culture system on the nutrition and growth performance of Pacific white shrimp Litopenaeus vannamei (Boone) fed different diets. Aquaculture Nutrition, 8: 121-137.

Velázquez-Chavarría, L. 1999. Nuevos parámetros de crecimiento de los camarones peneidos comerciales de la costa caribe nicaraguense. Centro de Investigaciones Pesqueras y Acuícolas (CIPA), Instituto Nicaraguense de la Pesca (INPESCA), Managua, 7 pp.

Vilasboa, A., Alencar, A.S., Duarte, A.V.B., Tavares, C. \& Gusmão, J. 2018. Haplotype-specific single-locus multiplex PCR assay for identification of Pacific and Atlantic white shrimps, exotic Litopenaeus vannamei and native Litopenaeus schmitti, along the coast of Brazil. Conservation Genetics Resources, 12: 93-98.

Wakida-Kusunoki, A.T., Amador-del Angel, L.E., Carrillo, P.A. \& Quiroga, C.B. 2011. Presence of Pacific white shrimp Litopenaeus vannamei (Boone, 1931) in the southern Gulf of Mexico. Aquatic Invasions Records, 6: 139-142.

Wasielesky Jr., W., Poersch, L.H., Martins, T.G. \& Miranda-Filho, K.C. 2017. Chronic effects of nitrogenous compounds on survival and growth of juvenile pink shrimp. Brazilian Journal of Biology, 77: 558565.

Williams, A.S., Davis, D. \& Arnold, C.R. 1996. Densitydependent growth and survival of Penaeus setiferus and Penaeus vannamei in a semi-closed recirculating system. Journal of the World Aquaculture Society, 27: 107-112.

Wyban, J. 2007. Thailand's white shrimp revolution. Global Aquaculture Advocate, 42: 56-58. 